\title{
Australian Intellectual and Popular
}

\section{Responses to China's Rise}

\author{
Colin Mackerras
}

Abstract: This chapter understands 'popular' responses as those from people with no specialist interest in China, as expressed through surveys, and represented in various outlets, including newspaper and other articles, and online comments on these. 'Intellectual' responses mean mainly those of specialists, as expressed in academic and research articles and books coming from scholarly publishers or in newspaper articles and interviews that explain such opinion. China's 'rise' is taken as its increase in economic, politico-strategic and cultural power, especially since about 2005.

Australians' images of China have been mixed, and the chapter will analyse several initiatives in responding to China's rise. Most important was the 2010 essay 'Power Shift' by Hugh White of the Australian National University, which argued for a decisively new Australian response to China's rise. White followed up with a book-length study published in August 2012. His ideas have provoked heated journalistic and academic debate.

Late in 2012, the federal government issued a white paper on 'Australia in the Asian century'. Although the paper is about Asia in general, not just China, there is much focus on the rise of Asia, including that of China. This chapter takes some account of ideas from the white paper.

Several developments suggest that attitudes of suspicion about China may be on the rise in Australia. Among others, these include hostility in some quarters to Chinese investment and sale of property, especially over Cubbie Station in Queensland to mostly Chinese interests in 2012. The paper will consider processes and reasons for the apparent shift in public opinion.

Keywords: China's rise, Australia, popular opinion, intellectual opinion, trade and investment, strategic balance of power

\section{INTRODUCTION}

The aim of this chapter is to analyse and explain Australian attitudes and responses towards China's rise. Although this rise has been going on for some time now, it has accelerated in the twenty-first century, and that is the period that forms the object of responses in this chapter. As for the responses themselves, they date mainly from 2005, a year when positive images of China appear to have reached their height. The end time is the beginning of 2013, that being when the writing of the chapter was finished.

In terms of content, these responses are mainly in the economic and strategic fields. Although economic and strategic responses are nothing new, they have changed in type and intensity with China's rise. Another response to China that gains a great deal of publicity is in the field of human rights. These are not considered in great detail here, because they have not be 
affected crucially by China's rise, except insofar as economic imperatives tend to lessen the impact of human rights interventions.

The attitudes under discussion are of two main kinds, intellectual and popular. Of course, there is overlap between these two, but they are different fields all the same. Intellectual opinion is defined as that based on research, most of which is carried out in universities or other tertiary-level educational institutions. Popular attitudes are understood as those reflected in the media and surveys or opinion polls. Among opinion polls, by far the most thorough and important are those carried out by the Lowy Institute for International Policy, a high-ranking independent think-tank set up in 2003 by leading Australian businessman Frank Lowy. Since 2005, the Lowy Institute has been undertaking annual public opinion polls on various international questions, its methodology being to carry out telephone interviews with some 1000 Australians aged 18 and over, with equal numbers of men and women.

The sources and methodology follow directly from these definitions. For intellectual responses, books and articles by specialists are analysed to show a range of opinion. To define a specialist precisely is not straightforward. Academic specialists on China can include not only those who focus all or most of their attention on that country, but also scholars who specialize in a discipline like international relations or economics in which China is a major target of study. Moreover, there are journalists and politicians who specialize in China. Does their work reflect popular or intellectual opinion, or both? In this chapter I analyse some of their work and context helps to decide the category to which particular ideas belong. Sources for popular opinion include newspaper articles and media reports as well as professional opinion surveys dating from 2005 or since then. A major particular source is the government white paper entitled Australia in the Asian Century, which came out in October 2012 and strove to outline a generalized policy on how Australia should respond to the brilliant economic and other growth in Asian countries, including China. Reports are taken as examples of particular opinions and attempts will be made to try and balance these and to put them into context.

The Australian context is of a liberal democracy that has remained very loyal to the United States, a country with which it signed a security treaty with the acronym ANZUS (Australia New Zealand United States) in 1951. Although this has not prevented it from pursuing its own national interests, it has tended to follow American policy in the Pacific, including towards China. From 1996 to 2007, the national government was dominated by a conservative Coalition of the Liberal and National Parties, with the Liberal leader John Howard as prime minister. In November 2007, the Australian Labor Party (ALP) won national elections, bringing to power Prime Minister Kevin Rudd, extremely unusual among Western leaders in being able to speak Chinese and having specialist knowledge of China. He was overturned as prime minister in June 2010 and replaced by his deputy Julia Gillard, who stayed on as prime minister at the head of a minority ALP government after an election held in August 2010.

In economic terms, Australia has done well in the twenty-first century so far. It has continued positive growth and low unemployment rates. It avoided the worst ravages of the Global Financial Crisis that began in 2008. One of the prime reasons for this was the resources/minerals trade with the rising China, where the rapidly expanding economy required the coal, iron ore, liquefied natural gas and other products that Australia provides so 
readily. A situation of mutual dependency has arisen. This is by no means total in that Australia has other markets and China has other sources of supply. However, China can more easily compensate in resource products from elsewhere, such as from Brazil or South Africa, than Australia can find markets of a scale that would make up for the loss of the China market, should that eventuality occur. The result is that Australia's economic dependence on China is much greater than the other way around. If China's growth rates were to slow significantly and over a substantial period of time, Australia's economy would suffer greatly, with social and political effects.

\section{INTELLECTUAL RESPONSE TO CHINA'S RISE}

Since the American alliance is the basis of Australia's foreign policy, it is not surprising that intellectual response to China's rise should to a large extent revolve around the effects on the Australia-United States-China trilateral relationship. Comments on China's rise by strategic studies and other specialists and those working in universities have been quite various. Although there is a strong tradition of anti-Americanism in the universities, the anxiety about China that we shall see below as quite strong in popular opinion, also finds its reflection among specialists.

The revival of the 'fear of China' syndrome is a feature of the twenty-first century. Ironically, under the Howard government, both intellectual and government opinion seemed quite sanguine about the rise of China. It was under Howard that the rapid acceleration in Australia's trade with China began, especially in the minerals sector. Government opinion was quite explicit in rejecting the American view of the day that China's military expenditure was a cause for concern. ${ }^{1}$ However, the weight of opinion was that the US alliance was valuable for Australia and should stay in place. ${ }^{2}$ After all, Howard was famous for his pro-American stance in foreign policy, and as being a strong supporter of American President George W. Bush.

\section{Kevin Rudd, the 2009 Australian Defence White Paper, the China threat}

When Kevin Rudd was elected prime minister in November 2007, there was a widespread assumption that he would give China a higher priority than Howard had done. He had studied Chinese language and history at the Australian National University and written an honours dissertation on the dissident Wei Jingsheng. Although this chapter deals not with policy but with reaction to the rise of China, it seems to me legitimate to classify Rudd's ideas among the intellectual response rather than the popular.

Rudd gave several speeches on China as prime minister, showing his basic ideas about them. One was a major speech to the students of Peking University, which he gave, in Chinese, on 9 April at the University itself. Another was the $70^{\text {th }}$ Morrison lecture in Canberra in June 2010,

\footnotetext{
${ }^{1}$ See some brief commentary on Australian reaction to the rise of China during the Howard years in C. Mackerras (2011) 'The "China Threat" in the Context of China's Rise: A View from Australia', in H.S. Yee (ed.) China's Rise - Threat or Opportunity? (London and New York: Routledge), 216-21.

2 See, for example, A. Dupont (2007) 'The Virtues of the US Alliance', The Sydney Papers XIX (4), 53-8.
} 
two months or so before he was overthrown. The Morrison lectures are annual and called after George Ernest Morrison, an Australian who lived many years in China as a correspondent for The Times of London and was for a time adviser to the Republic of China's second president Yuan Shikai.

In these and other speeches, Rudd shows considerable knowledge of China and its history, far more than most Western leaders. His two main ideas appear to be that, although China has recently done brilliantly in economic terms, it would be good both for China and the world as a whole if China engaged 'across the board as major global stakeholder in the maintenance and enhancement' of a 'stable, rules-based order'. ${ }^{3}$ Although he does not spell it out, this rulesbased order is actually dominated by the United States, and implies that China should act in a way that takes less account of its own interests than of American. Another recurring point in Rudd's speeches is the notion of zhengyou ('true friend'). This can be defined as one who "'offers unflinching advice and counsels restraint" to engage in principled dialogue about matters of contention'. ${ }^{4}$

If there is a single document that attracted attention as signalling the re-emergence of the China threat idea in Australia it was the Australian Defence White Paper (ADWP), which came out on 2 May 2009, that is, during Kevin Rudd's prime ministership. Actually, it must be said in fairness that the white paper does not mention China as a threat, though it does signify keen awareness of China's rise. Its main thrust, despite the budgetary exigencies occasioned by the Global Financial Crisis, was to make the biggest increases in military spending since the end of World War II, especially in the navy, with projections made to 2030 . The grounds were that the coming period would see declining American involvement in the defence of the region and that the need for Australia to be able to defend itself was thus greater than it had earlier been.

There was a good deal of commentary on why this increase should be necessary. Was there a threat to Australia and, if so, where did it come from? To many observers the answer was that the increase did indeed come from an increased threat, and that the main source was indeed China. $^{5}$

What about the Chinese? Although Australian government spokespeople suggested that Chinese officials were happy with the document, this is highly unlikely. The following comment by You Ji seems much nearer the mark.

From the Chinese perspective, the ADWP is seen to be symbolic of Canberra scapegoating China in order to please the US. China policy was readjusted against a background of Washington's displeasure over Australia's leaning towards Beijing. Howard openly dismissed the thesis of a China threat and depicted Australia-China ties in terms of a

\footnotetext{
${ }^{3}$ K. Rudd (2010), 'Australia, China and the World', $70^{\text {th }}$ Morrison Lecture, held at the Australian National University on 23 April 2010, web version, accessed 27 December 2012, at http://pmrudd.archive.dpmc.gov.au/node/6700.html.

${ }^{4}$ See Rudd's Peking University (Beida) speech: K. Rudd, 'Beijing University Speech by Australian Prime Minister Kevin Rudd', The Australian, 9 April 2008, web version, accessed 27 December 2012, at http://www.theaustralian.com.au/news/kevin-rudds-speech-at-beijing-uni/story-e6frg6n61111116015758 . He used identical wording in Rudd, 'Australia, China and the World'.

${ }^{5}$ For some brief commentary on the early Rudd period in Australia, down to the 2009 ADWP, see Mackerras, 'The "China Threat" in the Context', 222-5.
} 
strategic partnership, a most positive characterisation by a US ally for a US competitor.... US suspicion of a Mandarin-speaking PM being overtly friendly towards China seemed to be substantiated by Kevin Rudd's first few months in office. ${ }^{6}$

Like more or less all government documents, the ADWP was a collective effort, with the Australian Minister of Defence Joel Fitzgibbon closely involved. However, there is little doubt that Kevin Rudd took a keen interest and that he was the person whose ideas were most closely reflected in the document. It also seems clear that Rudd saw the Australian defence and naval build-up as aimed mainly against China. In his public pronouncements, such as the $70^{\text {th }}$ Morrison lecture, he has mentioned the China threat theory, without either affirming it or disagreeing with it. ${ }^{7}$ However, according to a WikiLeaks revelation of 5 December 2010, Rudd had told American Secretary of State Hillary Clinton just before the ADWP was released that he regarded himself as a 'brutal realist on China' and that the white paper was aimed at responding to 'China's growing ability to project force' ${ }^{8}$

Another person to have exerted some influence on the 2009 ADWP is Professor Ross Babbage AM, who is one of the most experienced strategic studies thinkers in Australia. He needs discussion here not only for his impact on government thinking, but also because he is one of the most important, perhaps the main, Australian representative of the kind of thinking that sees a military threat from China in the next two decades as likely enough that Australia should take concrete measures to defend itself against that possibility. Formerly a strategic studies professor at the Australian National University and adviser to governments on strategic matters, he is a founder of the Canberra-based Kokoda Foundation, a body that carries out research on strategic matters and works closely with the Australian government. He is unusual in serving in senior positions in academia, government and business, but unquestionably belongs in the 'intellectual' not 'popular' category.

Like the ADWP, Babbage envisions what Australia's security environment is going to be like by 2030. He believes Australia should not seek to confront China. However, over the next decades it should shore up its defences, jointly with the United States, to guard against the possibility of an attack. This has become more likely, because the United States is undergoing deep economic crisis, which can only have the effect of weakening it in the overall strategic balance of power, while China is rapidly increasing its strength in the West Pacific. Babbage is quite specific about the military needs. His preferred option is as follows:

Heavy investment would be made in regional engagement, cyber capabilities, both inhabited and uninhabited underwater systems (including, potentially, nuclear-powered attack submarines), advanced air combat capabilities and also a substantial

\footnotetext{
${ }^{6}$ You, J. (2012) 'Managing Off-Balance Tripartite Relations: How to Avoid Unnecessary Confrontation', in Reilly and Yuan (eds) Australia and China at 40, 95.

${ }^{7}$ Rudd, 'Australia, China and the World'. Specifically he lists several Western views of China, headed by a 'hardline view that regards China as a threat to the existing global order no matter what', then goes on to list 'certain core unassailable facts', which do not include any statement on the China threat.

${ }^{8}$ R. Callick (6 December 2010), 'Rudd's Brutal Reality Exposed', The Australian, web version, accessed 26 December 2012, at http://www.theaustralian.com.au/national-affairs/opinion/rudds-brutal-realityexposed/story-e6frgd0x-1225966033864.
} 
reconfiguration of ground forces with an emphasis on next-generation special force operations. ${ }^{9}$

In a radio interview on the Australian Broadcasting Corporation in October 2012, Babbage spoke in detail about his opinions. He expressed the belief that a major and possibly longlasting crisis involving military conflict between the United States and China could not be ruled out within the next decades, and that Australia would inevitably be drawn in on America's side. He said that a group of defence and security experts he had worked with had voted the likelihood of a military conflict between China and the United States in the coming decades at about 30 per cent, a surprisingly high possibility. He went on that any house-owner would pay quite a bit to take out insurance against a very much lower likelihood than 30 per cent, and that Australia as a nation should do the same. ${ }^{10}$

As one might expect, Babbage's views have come under criticism. Two eminent strategic studies specialists from the Australian National University, Geoffrey Barker and Paul Dibb, have attacked them as 'a recipe for confrontation with China', even though he says that is precisely what he is hoping to avoid. According to these two scholars, Babbage's proposals as outlined above 'turn reasonable concerns about China's military expansion into responses that verge on hysteria'. ${ }^{11}$ It is notable that they do not dismiss China's military rise out of hand, but do issue a forthright challenge to Babbage's analysis and proposals.

\section{The 'Power Shift' debate}

An important milestone in the debate on the implications of China's rise came in 2010, when the Australian National University professor of Strategic Studies Hugh White 'proposed the once unthinkable in Australia policy thinking by suggesting that the usefulness of Australia's alliance with the United States in its current form may be coming to an end', ${ }^{12}$ because of the rise of China and the potential that it might replace American dominance in its region. The specific article to draw this comment was entitled 'Power Shift' ${ }^{13}$ and, although not the first in which White began to put forward his views, it aroused the most public attention and controversy. White's analysis and recommendations for how Australia should respond to China's rise are extremely different from Ross Babbage's, though they share some basic assumptions. It is useful therefore to look at his arguments in some detail, as well as the response to them.

\footnotetext{
${ }^{9}$ R. Babbage (February 2011) Australia's Strategic Edge in 2030 (Kokoda Paper No. 15, Canberra: The Kokoda Foundation), ix.

10 'Interview: Ross Babbage' (26 October 2012), Friday Late programme, ABC News, web version at http://www.abc.net.au/news/2012-10-26/interview-ross-babbage/4336622, accessed 26 December 2012.

${ }^{11}$ G. Barker and P. Dibb (21 February 2011), 'Is China a Military Threat to Australia? The Babbage Fallacies', East Asia Forum, Economics, Politics and Public Policy in East Asia and the Pacific. East Asia Forum is an on-line journal based at the Crawford School of Public Policy at the Australian National University.

12 M. Heazle and M. Clarke (November 2012) 'Old Problems in a New Century?', Australian Journal of International Affairs, LXVI (5), 498.

${ }^{13} \mathrm{H}$. White (2010) 'Power Shift: Australia's Future between Washington and Beijing', Quarterly Essay, XXXIX, 1-74
} 
Already in 2005, White was suggesting that China's rise would lead to serious tension with the United States, because he thought it unlikely that China would indefinitely accept American primacy. He argued that 'Australia's interests would be best served by an agreement between the US and China to share power in the region between themselves, and with others'. ${ }^{14} \mathrm{He}$ advocated a kind of 'new "Concert of Asia"' 15 similar to the Concert of Europe of 1815, which, following the Napoleonic wars, had prevented a major European conflagration in the nineteenth century until its collapse with the outbreak of World War I in 1914. Just as the Concert of Europe had necessitated that the major powers recognize the equal legitimacy of each other's governments and be prepared to accommodate and compromise in order to preserve peace, the new 'Concert of Asia' would see the United States and China recognize each other's government's equal legitimacy, each being willing to accommodate interests for peace.

'Power Shift' came out just after the $\mathbf{2 0 1 0}$ federal elections in Australia. This has brought about a hung parliament in which the ALP leader Julia Gillard succeeded in remaining in government by negotiating the support of two independents representing conservative electorates. By that time the Australian economy's dependence on Chinese economic growth had accentuated and China had become Australia's top trading partner through the purchase of energy products such as iron ore and coal in exchange for processed goods. China's rise showed no signs of slowing significantly, let alone stopping, and Nobel Prize-winning economic Robert Fogel had not long before predicted that by 2040 China' share of world GDP would be 40 per cent, as against only 14 per cent for the United States. ${ }^{16}$ Did it matter that Australia's top trading partner was not only different from its main strategic ally, but the two were potential enemies? Was this a situation that could continue indefinitely?

White certainly regarded it as a problem. In an abbreviated version of his essay published in Australia's most important scholarly journal of international affairs, he writes:

We assume that we can continue to grow rich on China's economic rise while remaining secure thanks to America's domination of Asia. But if China grows fast enough to power our economy as we hope and expect, it will become too strong to fit into the old US-led order that has served us so well. ${ }^{17}$

White was prepared to give John Howard some credit at least for realizing the problem and using commonsense, even if persisting in what was in effect a double game: 'Behind his overt fealty to Washington, he increasingly acknowledged China's growing strategic weight, blithely assuring Australians that they need not choose between America and China, while in reality he was already starting do so. ${ }^{18} \mathrm{He}$ is somewhat less kind about Rudd, accusing him of appealing

\footnotetext{
${ }^{14} \mathrm{H}$. White (December 2005) 'The Limits to Optimism: Australia and the Rise of China', Australian Journal of International Affairs, LIX (4), 473.

${ }^{15}$ White, 'The Limits to Optimism', 469.

${ }^{16}$ R. Fogel (January/February 2010) '\$123,000,000,000,000**China's Estimated Economy by the Year 2040. Be Warned', Foreign Policy, web version, accessed 27 December 2012, at http://www.foreignpolicy.com/article/2010/01/04/123000000000000 .

${ }^{17} \mathrm{H}$. White (2011), 'Power Shift: Rethinking Australia's Place in the Asian Century', Australian Journal of International Affairs, LXV (1), 82.

${ }^{18}$ White, 'Power Shift: Rethinking', 82-3.
} 
to xenophobia 'by conjuring alarming images of a China threat', ${ }^{19}$ even though fully aware of the problem for Australia posed by China's rise. There is some discussion on Rudd's views above, so there is no need for recapitulation here. As for Rudd's replacement Julia Gillard and her Coalition counterpart Tony Abbott, White is quite dismissive, charging that they have given the issue no serious thought. He adds: 'They need to start thinking about it now. So do the rest of us. ${ }^{20}$

One big problem associated with White's theory, and he acknowledges it himself, is America's reaction. The fact is that a great power such as the United States is rarely willing to share power with others, let alone with a country it has traditional thought of as inferior, more like a wayward student than an equal, a country with an authoritarian political system that should, in the American view, quite obviously adopt United States-style democracy. As he puts it in a full-length book entitled The China Choice and published in 2012: 'Sharing power with China runs counter to America's vision of itself and its role in the world'. ${ }^{21}$

From Australia's point of view, the main question is one already implied in the 2012 book's title. Does Australia have to choose between China and the United States? Cannot it simply continue to trade with China, using economic relations with that country to keep its economy prosperous, but at the same retain its security treaty with the United States? For the time being it may be able to do that. However, White is in no doubt that eventually tensions, even conflict, between the United States and China are going to force hard choices to be made. It is better for Australia's leaders to make the choice while debate and consideration are still possible, rather than finding themselves faced with an instantaneous decision forced on them through a crisis. ${ }^{22}$ What White is suggesting, in essence, is that Australia should undertake a thorough-going review of its foreign policy, leaving open the possibility of distancing itself from the United States and even discontinuing the ANZUS alliance and moving significantly towards China.

As an example of potential conflict, White pointed to Sino-Japanese relations, which grew notably tenser as China's rise accelerated. In December 2012, an election brought to power with a landslide majority the conservative Liberal Democratic Party leader Abe Shinzo, who had a reputation for his anti-China, even nationalist stance. In an article published at the end of the year, White wrote: 'don't be too surprised if the US and Japan go to war with China next year over the uninhabited rocks that Japan calls the Senkakus and China calls the Diaoyu islands. And don't assume the war would be contained and short'. To solve the problem advocated 'creative diplomacy' of the kind that 'can find a face-saving formula that defuses the situation by allowing each side to claim that it has given way less than the other'. ${ }^{23}$ This prediction is so extreme as to be surprising, but the recipe for solution is in line with his thinking in 'Power Shift'.

\footnotetext{
${ }^{19}$ White, 'Power Shift: Rethinking', 83.

${ }^{20}$ White, 'Power Shift: Rethinking', 83.

${ }^{21}$ H. White (2012) The China Choice, Why America Should Share Power (Collingwood, Victoria: Black Inc.), 155.

${ }^{22}$ White The China Choice, 154.

${ }^{23} \mathrm{H}$. White (26 December 2012). 'Caught in a Bind that Threatens an Asian War Nobody Wants', Sydney Morning Herald, web version at http://www.smh.com.au/opinion/politics/caught-in-a-bind-thatthreatens-an-asian-war-nobody-wants-20121225-2bv38.html, accessed 27 December 2012.
} 
Although not many strategic thinkers wanted to go as far as Hugh White in urging greater independence of the United States, moderates admired his highlighting the issue. Two younger scholars provide a good example. They wrote that White had played 'an important role in making the uncertain nature of Australia's future security in Asia an issue of much needed public debate', ${ }^{24}$ and especially in terms of the implications of China's rise.

There has a range of reaction to the question of Australia's alliance with the United States and White's proposals. Some have been very hostile. One response to White's essay 'Power Shift' equates his thinking to appeasement, pure and simple. Written by an ALP member of the House of Representatives known for his pro-Israel, pro-United States but anti-China views (Michael Danby), and two strategic studies academics (Carl Ungerer and Peter Khalil), it concludes.

Australia certainly needs to find a way to live alongside a powerful and prosperous China. We do that best by building our mutually advantageous economic relationship, by staying loyal to our friends in the region, by assisting the US to maintain its role in the region, and by standing by our belief in democracy and human rights for all countries, including China. We don't serve anyone's interests by trying to appease the present regime in Beijing. ${ }^{25}$

In other words, Australia should do anything but encourage the United States to share power with China. Australia should keep its alliance with the United States. In the sense that it should make a choice, that should go to the United States, certainly not China.

\section{The economic dimension}

In his well-publicized speech delivered at Peking University on 9 April Kevin Rudd raised an issue in relations with China that applies to a great many countries around the world. He mentioned anxiety in Australia about China's growth because some people were nervous 'about their job moving to China'. ${ }^{26}$ What he meant was that goods could be produced more cheaply in China because of lower wages and worse conditions, as a result of which some Australian workers would lose their jobs in favour of Chinese.

\footnotetext{
${ }^{24}$ Heazle and Clarke, 'Old Problems', 499.

${ }^{25}$ Michael Danby, Carl Ungerer and Peter Khalil (2010), 'No Winners by Appeasing China', The Australian, 16 September, web version, accessed 24 December 2012, at http://www.theaustralian.com.au/opinion/no-winners-by-appeasing-china/story-e6frg6zo1225924276179. An even more strident opinion came from journalist Greg Sheridan, Foreign Editor of The Australian, but at the time visiting scholar at the Woodrow Wilson International Centre for Scholars in Washington, who called it 'the single, stupidest strategic document ever prepared in Australian history by someone who once held a position of some responsibility in our system (White was once deputy secretary of the Defence Department)'. See G. Sheridan (11 September 2010), 'Distorted Vision of Future US-China Relations', The Australian, web version, accessed 24 December 2012, at http://www.theaustralian.com.au/opinion/distorted-vision-of-future-us-china-relations/story-e6frg6zo1225917582189.

${ }^{26}$ K. Rudd (9 April 2008), 'Beijing University Speech by Australian Prime Minister Kevin Rudd', The Australian, web version, accessed 26 December 2012, at http://www.theaustralian.com.au/news/kevinrudds-speech-at-beijing-uni/story-e6frg6n6-1111116015758.
} 
In part, argument over the role of China in Australia's strategic thinking lies in the fact that the country has become so important in Australia's economy. Not only is China Australia's largest trading partner, but investment is growing rapidly. Most important of all, the fact that China buys so many mineral products from Australia has been one of the most important factors, if not the main reason why the Australian economy has done well in recent years, avoiding the recession that has plagued many Western economies since the Global Financial Crisis struck in 2008.

What does this economic dependence imply? Does it mean that Australia has to conciliate China for fear that it will lose markets to other countries with similar natural resources, such as Brazil? Or alternatively, should Australia try consciously to reduce this dependence in order to avoid become dependent on China in other ways, such as political or strategic?

Michael Wesley, who already has a long a distinguished career both in academia and government, was appointed as professor of National Security at the Australian National University in November 2012. He approaches the question of China's potential 'economic leverage' against Australia. He argues that China has so far not 'tried very hard to use this leverage' in Australia or any other country that has some kind of economic dependency relationship, and that it has 'not worked out how to use economic leverage effectively'. ${ }^{27}$ Brazil's iron ore may be better in quality than Australia's, but is more expensive to transport since Brazil is much less accessible to China than is Australia. Wesley is not concerned either that China will pull the rug from under Australia's feet or that it will seek to dominate Australia politically and culturally.

John Lee, who is at the Centre for International Security Studies at the University of Sydney, shares some of Wesley's viewpoints, but from a very different perspective, one somewhat more critical of China. He talks not of China's economic leverage but of its ability to 'punish' countries that defy its will. In essence this view sees China's power as limited, now and in the future. It would not be wise to allow strategic relations in the Asia-Pacific region to be influenced by China's growing economy. He writes that:
strategic competition between America and many other countries in Asia on the one hand, and China on the other, is intensifying rather than subsiding. I argue that China's capacity to economically 'punish' countries (including commodity exporters such as Australia) is limited. Furthermore, Beijing's capacity to use China's economic size to exercise strategic leverage over regional capitals (including Canberra) is restricted - even if China continues to grow rapidly. For this reason, even though further tensions between Beijing on the one hand, and Washington and other Asian capitals on the other, will remain and probably deepen, it will be neither desirable nor necessary for Australia to shift its strategic trajectory towards China and away from our alliance with America. ${ }^{28}$

John Lee did not put forward his argument in the context of Hugh White's theories but in that of evaluating the $40^{\text {th }}$ anniversary of the establishment of diplomatic relations between Australia and China. However, there is no question but that he disagrees strongly with White

\footnotetext{
${ }^{27}$ M.Wesley, 'Australia and the China Boom', in Reilly and Yuan (eds) Australia and China at 40, 203.

${ }^{28}$ Lee, J. (2012) 'Divergence in Australia's Economic and Security Interests?', in Reilly and Yuan (eds)

Australia and China at 40, 144.
} 
and sees the 'power shift' as overblown. Views that equate China's economic rise in Australia with some kind of incipient colonialism belong more to the popular than intellectual realm and will be discussed in more detail below.

\title{
POPULAR RESPONSE TO CHINA'S RISE
}

We turn now to the popular views in Australia about China's rise. In general terms, Australians feel fairly warmly towards China, but less so than towards several other countries, especially New Zealand, the United States and Japan, in that order. The Lowy Institute has since 2006 taken a measurement of warmth towards other countries, with $0^{\circ}$ representing the coldest to the warmest at $100^{\circ}$. For China the overall trend was downwards from over $60^{\circ}$ in 2006 to $53^{\circ}$ in 2011 , but there was then a sharp rise to $59^{\circ}$ in 2012 . In that last year, the ratings for New Zealand, the United States and Japan were $85^{\circ}, 71^{\circ}$ and $70^{\circ}$ respectively. ${ }^{29}$

Journalist David Uren, economics editor of The Australian, has written as follows about Australian images of China in the period of concern to this chapter.
There are the two Chinas in the Australian mind: the bottomless market and the menacing other. The first ... shapes the economic policy of Treasury and the Reserve Bank. It transforms Australia's place in the global economy, and the influence of the global economy on Australia.
The second breeds plans to spend $\$ 35$ billion buying a dozen submarines equipped with cruise missiles capable of reaching Tiananmen Square and binds Australia ever more tightly in military alliance with the United States. The distrust of an alien state also seeps into the economic sphere, influencing the management of investment in resources, agricultural land and housing. ${ }^{30}$

As Uren makes clear in this extract, the 'bottomless market' is an economic image and mainly positive, the 'menacing other' is entirely negative and largely strategic, but still with important economic factors.

\section{'The bottomless market' and economic relations}

The opening words of the executive summary of the government white paper Australia in the Asian Century are a strong statement of the importance of Asia to Australia. They read as follows:

\begin{abstract}
Asia's rise is changing the world. This is a defining feature of the 21st century-the Asian century. These developments have profound implications for people everywhere.

Asia's extraordinary ascent has already changed the Australian economy, society and strategic environment. The scale and pace of the change still to come mean Australia is entering a truly transformative period in our history.
\end{abstract}

\footnotetext{
${ }^{29}$ Fergus Hanson (2012) The Lowy Institute Poll 2012, Australia and New Zealand in the World, Public Opinion and Foreign Policy (Sydney: Lowy Institute for International Policy), 3.

${ }^{30}$ David Uren (2012) The Kingdom and the Quarry, China, Australia, Fear and Greed (Collingwood, Victoria: Black Inc.), p. 8.
} 
Within only a few years, Asia will not only be the world's largest producer of goods and services, it will also be the world's largest consumer of them. It is already the most populous region in the world. In the future, it will also be home to the majority of the world's middle class. ${ }^{31}$

Although the extract mentions factors other than economics and talks about Asia, not China, it already sets the tone for the strongly instrumentalist focus. There is a very strong potential for economic and social gain in Australia through economic engagement with China. There are cultural ways in which Australia can gain through engagement with China, but it is the economy that counts.

A couple of issues in popular opinion are quite revealing in economic attitudes towards China. On the proposition that 'China's growth has been good for Australia', the 2008 poll found 63 per cent in agreement, rising to 73 per cent in 2010 and 75 per cent in 2011. ${ }^{32}$ Another very interesting question asked in the 2012 poll concerned the reasons why Australia had been able to avoid recession. According to 70 per cent of people surveyed, a major reason was because of demand for Australian resources from countries like China, while 22 per cent thought this demand a minor reason, and only 6 per cent did not think it mattered. The reason most often promoted by the government was of course its own 'good Australian government policies'. However, only 41 per cent thought these a major reason, 36 per cent a minor reason, and 21 per cent not a reason at all. ${ }^{33}$ In other words, 70 per cent as against 41 per cent were prepared to give the main credit for avoiding recession to China and countries like it rather than to the government and its policies.

Although Australians are generally in support of China's economic involvement in Australia, limits to this approval have become very clear in the last few years. One issue is that of Chinese investment in Australian companies and resources. Although there was nothing new about Chinese foreign direct investment in Australia, let alone that from other countries, it was in 2008 that the issue became highly controversial politically.

In February 2008, the major state-owned investment management and holding company, the Aluminium Corporation of China (Chinalco), bought 12 per cent of shares of mining giant Rio Tinto's London-based stocks. Valued at about US\$14 billion, this was the largest single foreign investment by a Chinese company up to that time. The giant resources company BHP Billiton had just put forward a bid for a merger with Rio Tinto, and Chinalco's stated aim was to prevent the emergence of a monopoly that would be able to influence prices in a way directly against Chinalco's interests. In February 2009, Rio Tinto chief executive Tom Albanese revealed a plan whereby Chinalco would inject an even larger sum into Rio Tinto. By that time the Global Financial Crisis had sharpened enormously, and Rio was in dire straits financially. ${ }^{34}$

\footnotetext{
${ }^{31}$ Australian Government (October 2012) Australia in the Asian Century, White Paper (Canberra: Commonwealth of Australia), 1.

32 Fergus Hanson (2011) The Lowy Institute Poll 2011, Australia and the World, Public Opinion and Foreign Policy (Sydney: Lowy Institute for International Policy), 11.

${ }^{33}$ Hanson, The Lowy Institute Poll 2012, 12.

${ }^{34}$ The whole sorry saga of Chinalco and Rio Tinto is discussed in great detail in Chapters 5 and 6 of Uren, The Kingdom and the Quarry.
} 
The whole affair aroused great political debate and fury in Australia revolving around the fact that Chinalco was a state-own enterprise, making its purchase of Australian interests tantamount to sale of Australia to the Chinese government. The main opposition was an unlikely combination of the National Party, the Australian Workers' Union and the Greens. The National Party Senator Barnaby Joyce ran a series of television advertisement charging that the Rudd government was selling Australian to the Chinese government. Australian Workers Union National Secretary Paul Howes denounced Chinalco as 'a state-owned corporation integral to Chinese economic policy', which was 'not an independent entity'. Greens leader Bob Brown attacked Wayne Swan for entertaining the proposed deal between Rio Tinto and Chinalco 'when the Communist dictatorship will be pulling the strings behind the scenes' ${ }^{35}$

In the end the deal failed, and Chinalco's rival BHP Billiton had its offer accepted. Rio Tinto's big London investors declared that commercial factors pointed against Chinalco. In effect they were coming to the aid of the Australian government, which could now totally avoid the issue of whether political or commercial factors had influenced the outcome. It could maintain its traditional stance that Australia practises a non-discriminatory policy in foreign investment. In China, the State Council's Development Research Centre put out a detailed and thoughtful report on the matter, which put a good deal of weight on the commercial factors and also stated: 'BHP Billiton took advantage of its skilful mass media propaganda and lobbying capacity to arouse the public emotions so as to influence the judgement of the government policy makers. BHP Billiton tightly seized the point that Chinalco had the state-owned background. ${ }^{36}$ Though in calm terminology, it definitely hinted at discrimination against China.

Although Chinalco's bid was ultimately unsuccessful, Australians in general have remained sceptical about Chinese (or any other) investment. The Lowy Institute polls of 2010 and 2011 found 57 per cent of Australians with the view that 'the Australian government is allowing too much investment from China'. ${ }^{37}$ In the 2012 poll, the figure was 56 per cent. In all years older people tend to be more resistant to Chinese investment than younger. In 2012, the interviewers proposed reasons for resisting Chinese investment. Those attracting most support went to the need to keep mining and agricultural companies in Australian hands, with 51 per cent of respondents expressing the fear that, through its investment, China 'could end up buying and controlling a lot of Australian companies'. Ironically, 46 per cent believed it was not only China but other countries too that were being treated too liberally by the Australian government in terms of investment. One suggestion was that 'a lot of Chinese investment is ultimately controlled by the Chinese government not private Chinese companies'. To this, 44 per cent of respondents expressed agreement, and 6 per cent disagreement. ${ }^{38}$

The total stock of Chinese foreign direct investment in Australia grew by an annual average 90 per cent between 2006 and 2011. This was ahead of Singapore, with 29 per cent annual average growth only. On the other hand, at the end of 2011, the list in descending size order of main foreign direct investors in Australia, together with the percentage share of the total FDI in parentheses, was as follows: United States (24.1), United Kingdom (13.7), Japan (10.3),

\footnotetext{
35 Uren, The Kingdom and the Quarry, 99.

${ }^{36}$ Uren, The Kingdom and the Quarry, 109.

${ }^{37}$ Hanson, The Lowy Institute Poll 2011, 11.

${ }^{38}$ Hanson, The Lowy Institute Poll 2012, 12.
} 
the Netherlands (6.5), Switzerland (4.5), Singapore (3.9), Canada (3.4), Germany (2.8), China, mainland (2.6), Hong Kong SAR (1.3). ${ }^{39}$ These figures do not support any fear campaigns. David Uren has aptly pointed out that a rational government response to the growth in China's demand for minerals in the first decade of the twenty-first century and later 'would be to develop policy that would support Australia's role as preferred supplier'. He concludes: 'Instead, policy has been cloaked in suspicion about the true intentions of a supposedly monolithic Chinese state'. ${ }^{40}$ That has been to Australia's detriment and discredit.

An interesting irony is that it was often the richest people who supported the Chinese markets, despite the state's rule by the Chinese Communist Party. Queensland mining magnate Clive Palmer is famous for his support for China. Opposition to the American decision to boost United States troops in Darwin found among its strongest opposition not from the left but from the rich. In mid-September 2012, billionaire business leader Kerry Stokes attacked the government over its decision to allow American troops to be stationed in Darwin, saying he felt 'physically repulsed by the thought of armed people on my soil not being under our command'. He was supported by another billionaire, casino mogul James Packer, who commented that 'China has been a better friend to us than we have been to China'. ${ }^{41}$

In 2012, the Lowy Institute Poll included several new questions that had gained particular relevance over the preceding year. One of these was foreign ownership of agricultural land. This question drew significant opposition from Australians, with no less than 81 per cent saying they were against 'the Australian government allowing foreign companies to buy Australian farmland to grow crops or farm livestock'. Among this 81 per cent, 63 per cent were 'strongly against', the remaining 18 per cent 'somewhat against'. ${ }^{42}$

Of course these opinions are not directed only against China, but against foreign countries generally. However, a couple of particular cases gained a great deal of publicity and involved China. By far the most important was the sale of Australia's largest cotton producer, the 96,000-hectare Cubbie Station in southern Queensland to mostly Chinese interests. In 2009 the station had been placed into voluntary administration due to debts reported at some $\$ 320$ million. A consortium led by the Chinese textile company Shandong RuYi Scientific and Technological Group Co agreed to buy at under $\$ 300$ million and, after imposing conditions, principally that RuYi's stake would be reduced from 80 to 51 per cent within three years, the Australian Treasurer Wayne Swan approved the deal at the end of August 2012.43

Even though the Chinese company had in effect saved Cubbie and management and operation remained in Australian hands, there were substantial misgivings about the sale in Australia. In

\footnotetext{
${ }^{39}$ NSW Government, 'Trade and Investment, Stock of Foreign Direct Investment in Australia by Country', at http://www.business.nsw.gov.au/invest-in-nsw/about-nsw/trade-and-investment/stock-of-foreigndirect-investment-in-australia-by-country, accessed 30 December 2012.

${ }^{40}$ Uren, The Kingdom and the Quarry, 111.

${ }^{41}$ A. Hepworth and A. White (15-16 September 2012), 'Business Hits out on China Ties', The Weekend Australian, 1.

42 Hanson, The Lowy Institute Poll 2012, 4.

43 J. Walker, 'Cubbie Station Sale a Disgrace, Says Barnaby Joyce', The Australian, 1 September 2012, web version, accessed 29 December 2012, at http://www.theaustralian.com.au/national-affairs/cubbiestation-sale-a-disgrace-says-barnaby-joyce/story-fn59niix-1226462779659.
} 
particular, National Party Senator Barnaby Joyce immediately attacked Wayne Swan for failing to preserve Australia's national interests and called the sale 'a bloody disgrace'. ${ }^{44}$ As seen above, Barnaby Joyce already has a reputation for his economic nationalism. In a speech on 14 September 2012 during the Australia in China's Century Conference held in Sydney, Swan counterattacked by saying: 'To have senior politicians to come out and behave in a xenophobic way is very damaging, not just to our economic prospects, but to our standing in the region'. ${ }^{45}$

\section{'The menacing other'}

The other side of the coin for David Uren is the threat that China poses, either actually or potentially. The Howard government was famous for its support of the American alliance and the ANZUS Treaty. This support has remained strong under the ALP governments. We saw above that a section of specialist intellectual opinion, headed by Hugh White sees the need for a re-evaluation of Australia's trilateral relations with the United States and China, with concern over future contention between these two affecting Australia's policy.

However, government and popular opinion in general are happy with the situation with the American alliance as it exists at present. The October 2012 white paper stated: 'Australia's alliance with the United States and a strong US presence in Asia will support regional stability, as will China's full participation in regional developments. ${ }^{46}$ According to one leading specialist, Michael Wesley, 'Opinion polling shows that ....over 80 per cent of Australians support the alliance with the United States. Over 70 per cent believe China is important to Australia's economic future. ${ }^{47}$ Neither government nor people appear to believe there is any real need to choose between the United States and China, at least not at present.

As for whether China's rise makes it a threat to Australia in any way, the evidence suggests that Australians have become more concerned since Rudd came to power in November 2007 than before. Despite its pro-United States stance, the Howard government was much more concerned about promoting trade with China than with viewing it as a threat. Minister for Foreign Affairs Alexander Downer said on 22 August 2001: 'The big strategic question of the twenty-first century is not how to contain China, or even to balance it'. He continued that such approaches 'imply that China is inherently a threat purely as a result of its size' and 'overestimate the degree to which China can really challenge the United States' pre-eminent position, even assuming that it wished to do so. ${ }^{\prime 48}$ This mode of thinking he regarded as definitely a mistake.

\footnotetext{
${ }^{44}$ Walker, 'Cubbie Station Sale a Disgrace'.

${ }^{45}$ A. White, 'Wayne Swan Says Comments on Cubbie Damage our Image', The Australian, 15 September 2012, web version, accessed 29 December 2012, at http://www.theaustralian.com.au//nationalaffairs/swan-says-comments-on-cubbie-damage-our-image/story-fn59niix-1226474548121.

${ }^{46}$ Australian Government, Australia in the Asian Century, 3.

47 Michael Wesley (2011), There Goes the Neighbourhood, Australia and the Rise of Asia (Sydney: University of New South Wales Press), 146.

48 The Hon. Alexander Downer, MP (22 August 2001), 'Gaining a Place: Integration in the Asia-Pacific', Opening address by the Hon Alexander Downer, MP, Minister for Foreign Affairs, at the UNSW/ADFA Conference on The Asia-Pacific Region: Policy Challenges for the Coming Decade, Canberra, web version,
} 
A similar approach emerged from the chapter on China's military modernization in a Senate Committee enquiry into Australia-China issued in March 2006. The document came out not long after the United States Department of Defense Report of July 2005 had taken a quite alarmist view on China's military expenditure and modernization. The Australian Senate Committee stated: 'Generally, evidence before the committee assumed a far less alarming tone', ${ }^{49}$ with Defence Minister Senator Robert Hill commenting: 'We certainly accept the right of China to modernise its armed forces. As the economy grows, as China plays a more forward role in the world, it's not surprising it wishes to improve its defence capabilities, so I understand that'. 50

We already noted above the Defence White Paper of 2009, reflecting Rudd's thinking. Comparing it with the Senate Committee's report, it betokens a rise in the fear of China and in the wish to contain it. We are certainly not back to the bad old days of the 1950s and 1960s when the fear of China exercised a dominating effect on Australia's foreign policy and community thinking. Indeed, the white paper of October 2012 mentions threats from 'nonstate actors like terrorists, traffickers, pirates, hackers or other transnational criminals' but not from China. It also says that Australia has 'a key interest in building defence and broader security cooperation with China'. ${ }^{51}$

However, the rising China is beginning to become more than just an opportunity for ensuring economic growth. Popular opinion broadly reflected this change. For instance, the 2012 Lowy Institute poll had 79 per cent of respondents agreeing that China is 'already the leading power in Asia', while 16 per cent agreed that 'it will become the leading power'. ${ }^{52}$ In other words all but 5 per cent belonged in one of those two categories.

While there is a trend towards more caution about China, it is by no means totally consistent. To the question whether China is likely to become a military threat to Australia in the next 20 years, a majority thought not, but a significant minority thought it was. Specific figures from 2009 to 2012, were 57 per cent, 52 per cent, 55 per cent and 58 per cent who thought China was unlikely to become a military threat to Australia over the next 20 years, while almost all the remainder believed it likely. ${ }^{53}$ There is a general but slight trend for the belief that China is likely to become a threat to be more prevalent among women than men, and among older than younger people. The most widespread reason for such a belief is as follows: 'China and the United States are likely to come into conflict in future and Australia will end up being drawn into the conflict through its alliance with the United States'.$^{54}$ What this suggests is a certain ambivalence about the effects of the American alliance on relations with China. Most people see no need to choose between the old and the emerging great power. But there are

at http://www.foreignminister.gov.au/speeches/2001/010822 fa integrate asia pac.html, accessed 31 December 2012.

49 The Senate Foreign Affairs, Defence and Trade References Committee (2006) China's Emergence: Implications for Australia (Canberra: Commonwealth of Australia), 91.

50 Senate ... Committee (2006) China's Emergence, 93.

${ }^{51}$ Australian Government, Australia in the Asian Century, 232.

52 Hanson, The Lowy Institute Poll 2012, 13.

53 Hanson, The Lowy Institute Poll 2011, 11, Hanson, The Lowy Institute Poll 2012, 13.

54 Hanson, The Lowy Institute Poll 2011, 12. 
some people who share Hugh White's concerns both about rising contention between the United States and China and about the effects on Australia's relations with both countries.

\section{CONCLUSION}

The basic conclusion is that the overall trend since 2005 is towards greater suspicion, sometimes approaching fear. This anxiety extends to Australia's economic dependence on China, because Australia is still tied to the United States culturally and ideologically, and people are very happy with that situation. This is especially the case in popular opinion, with some interesting and important divergent opinion in the academic sphere. A challenge to the status quo tends to be unwelcome. However, there are some daring scholars who are prepared to issue such a challenge despite the difficulties inherent in doing so.

There are five main reasons for this trend towards growing suspicion of China in Australia. The first and probably most important is that China's rise has consolidated, intensified and accelerated since the middle of the first decade of the twenty-first century. This is shown in China's economic, technological and military rise, and in its cultural confidence. Consciousness of rise inevitably breeds suspicion in the case of a country that has so often in the past been regarded as unfamiliar or even hostile.

Australia's dependence on China is directly related to its economic rise, because Australia provides many of the sources of energy that China needs. It is inevitable that economic dependence brings two consequences. One is a feeling of gratitude because of being rescued from the sort of economic troubles that have afflicted most advanced Western economies since the Global Financial Crisis of 2008. But the converse is a feeling of resentment. This is especially the case for a people that Australia, like other Western countries, has got to regarding as inferior technologically, economically and culturally.

Thirdly, China has become generally, although not consistently, more assertive with the passage of time. Nick Bisley is probably right to suggest that: 'Thus far, China's rise has clearly unsettled the region and, given the uncertainty about just how China will behave in the future, there is a strong chance that this will increase. ${ }^{55}$ Since this is not a paper on China's foreign relations, it is outside its scope to give details buttressing this view, but tensions emerging in the region and in the South China Sea since about 2009 exemplify the point.

Some of the responsibility for this increase in Australia's suspicions about China's rise lies also with Australia and the United States. The United States has been itself quite assertive in trying to show the world that it has no intention of giving up its strategic primacy. Barack Obama's attempts to project American power that included the 2011 decision to station more troops in Darwin, Australia, appeared to the Chinese and others to be aimed at letting the world know that it regarded China's rise as a strategic challenge that it not wish to accept.

The fifth and last reason for the growth in Australian suspicion of China is, ironically, Kevin Rudd's policy on China. He is the prime minister who knows most about China and that one

\footnotetext{
${ }^{55}$ Bisley, N. (2012), 'Never Having to Choose: China's Rise and Australian Security', in J. Reilly and J. Yuan (eds) Australia and China at 40 (Sydney: University of New South Wales Press), 70.
} 
might have expected that to inform him about how best to formulate policy. Yet his idea that as a true friend he can counsel the Chinese on human rights in minority areas and elsewhere seems to have irritated China, caused anger among them and consequent diminished trust on both sides. This contrasts with his predecessor John Howard, who tried more successfully to keep out of areas where China did not believe his intervention relevant or acceptable, and kept to economic dealings and building trade.

To be fair to Rudd, he faced a more difficult situation than his predecessor. It was not his fault that riots broke out in China's Tibetan areas in 2008, just after he had become prime minister. The intensification of China's rise, to which reference was made above, occurred when he was prime minister, forcing him to deal with it and not the more pragmatic Howard. The situation appears to have eased since he retired to the backbench, but it is still too early to say how long the reduction in tension will last. 